\title{
Toespraak by geleentheid van die gradeplegtigheid van regs- en teologiese studente - Universiteit van Pretoria, 27 Maart 1984
}

Appèlregter G Viljoen

Toe die versoek tot my gekom het om $u$ vanmiddag hier toe te spreek, het die vraag by my opgekom hoekom die Universiteit die twee groepe - teoloë en juriste - bymekaargegooi het vir doeleindes van hierdie gradeplegtigheid. Ek het nog nie vasgestel wat die Universiteit se beweegrede was nie. Dit mag toevallig wees of bloot om doelmatigheidsredes. Maar toe ek begin nadink het, het dit my onmiddellik getref dat die Christelike godsdiens en die RomeinsHollandse reg van die Afrikaner belangrike kultuurgoedere is wat 'n lang pad - 'n mens kan maar sê hand-aan-hand - oor die eeue ontwikkel en gedy het en opvallend dieselfde historiese pad geloop het om hier in die RSA gevestig te word.

Ek wil nie vanmiddag ingaan op ' $n$ vergelyking of oorvleueling of botsing tussen die wêreldlike reg en die kerkreg nie. Gedurende die Middeleeue het die kerkreg dikwels oortree op die gebied van die wêreldlike reg en het dit ook getrag om, wat die algemeen-menslike gedraginge en verhoudings betref, ordenend te werk te gaan. Vandag word die kerkreg in die Christelike kerk bekyk vanuit 'n redelik streng regs-teologiese oogpunt as reëlend alleen die orde binne kerkverband en nie die orde binne die staat nie. ' $n$ Vergelykende studie tussen kerkreg en wêreldlike reg sou 'n interessante studie wees, maar ek wil my beperk, in die kort tydjie tot my beskikking, tot'n breë historiese vergelyking.

Die Christendom het met die geboorte van Christus sy ontstaan gehad. Dit het geskied in die bloeitydperk van die Romeinse ryk toe ook die Romeinse reg 'n tydperk van ongekende ontwikkeling beleef het. Histories word die tydperk na die geboorte van Christus ingedeel in ' $n$ antieke, middeleeuse en moderne tydperk. Daar mag besware wees teen hierdie indeling, maar dit is 'n nuttige indeling om die ontwikkeling van die Christelike godsdiens en die Romeinse reg en later die Romeins-Hollandse reg te vergelyk. Die oorsprong 
van hierdie chronologiese indeling lê in die historiese beskouings van die humanistiese kringe. Die Renaissance-geleerdes het die tye wat onmiddellik hulle eie tydperk voorafgegaan het, beoordeel as tye van "duisternis", onkunde en barbarisme en dit het bekend gestaan as medium tempus. Die eie tyd is gesien as die tyd van die heerlike wedergeboorte van die antieke geleerdheid, taal, wetenskap en kuns. Die Middeleeue staan dus as ' $n$ minderwaardige tydperk teenoor 'n soort "goue tyd" van die antieke en meer verligte tyd. Dat daar wel ' $n$ mate van insinking was tydens die Middeleeue sowel wat die teologie as die regte betref, is waar, maar dit was nie heeltemal ' $n$ barre tydperk nie. Om 'n degraderende betekenis aan die term "Middeleeue" in die kerkgeskiedenis sowel as die regsgeskiedenis te heg asof dit ' $n$ minderwaardige periode is waarvan die bestudering minder belangrik is, is nie juis nie. Die Middeleeue was vir die teologie belangrik omdat dit sy eie inhoud, waarde en rykdom binne die kerkhistoriese ontwikkeling het. Ek is bewus daarvan dat die teoloë die Middeleeue sien as die tyd van die uitbreiding van die kerk oor Europa heen en onder die Slawiese volke. Die opkoms en bloei van die kerklike wetenskap, die stryd tussen pous en keiser, die bloei van die kloosterordes, ens. kenmerk hierdie periode.

Ook wat die Romeinse reg betref, het dieselfde proses plaasgevind. Justinianus was vanaf 527 tot 565 n C keiser van die Oos-Romeinse ryk. Hy het opdrag gegee dat die verspreide Romeins-regtelike tekste in een werk opgeteken word. Hierdie werk het later die naam Corpus Iuris Civilis gekry. Vir omstreeks 500 jaar na Justinianus was daar slegs sporadiese beoefening van die Romeinse reg, maar teen die elfde eeu het daar ' $n$ heroplewing van die studie van die Romeinse reg ingetree, en wel te Bologna in Italië. Interessant is die feit dat dit onder andere aan die Universiteit van Bologna in Italië is dat die kerkreg as wetenskap werklik beslag gekry het. Gratianus wat verbonde was aan die Universiteit van Bologna het ' $n$ verwerking van die hele Kanonieke reg aangepak en het 'n leerboek, die Corpus Decretorum die lig laat sien. Wat die Romeinse reg betref, het die skool van die Glossatore in hierdie tyd tot stand gekom. Hulle het hulle toegespits op die skryf van glossae, dit wil sê kort verklarende aantekeninge in die kantlyn van die teks van die Corpus Iuris. $\mathrm{Na}$ die Glossatore het die post-Glossatore, ook genoem die Kommentatore, gekom wie se werkmetode dit was om langer aantekeninge op die tekste te skryf, waarin die reg vertolk is, 'n sistematiek in die oënskynlike uiteenlopende tekste gesoek is en die reg ook 
herlei is tot die vraagstukke en toestande van die tyd. Dit kan aanvaar word, meen ek, dat daar 'n wisselwerking plaasgevind het tussen die Romeinse en die Kanonieke reg. Die Romeinse reg, soos vervat in die Justiniaanse kompilasie en soos verwerk deur die Italiaanse juriste, het met verloop van tyd sy invloed versprei oor die hele Wes-Europa, en mettertyd die ius commune van hierdie wêrelddeel geword.

Die hervorming het gekom en dit was, wat die kerk hier te lande betref, veral Calvyn wat in die sestiende eeu 'n besondere groot invloed uitgeoefen het. Sy werk was gerig op die kerk in Frankryk, maar sy invloed het ook uitgebrei na onder andere die Nederlande. In Frankryk het die hervormde Christene 'n moeiliker stryd gevoer as in Nederland. Hulle is vervolg deur die owerheid en dit is nie verbasend nie dat sommige van hulle na die Nederlande uitgewyk het waar die owerheid meer goedgesind was. Meer as ' $n$ eeu na die dood van Calvyn in 1564 het die Here XVII op 3 Oktober 1685 besluit om tot voortsetting van die landbou aan die Kaap en tot verligting van die garnisoen, 'n aantal koloniste na die Kaap te stuur. Hulle het besluit dat van hierdie koloniste Franse gereformeerdes kon wees. $\mathrm{Na}$ aanleiding van hierdie besluit het ' $n$ klein aantal Franse in 1685 na die Kaap gekom. Die groot groep sou eers in $1688 \mathrm{kom}$. Met hulle saam het hulle die hervormingstradisie gebring wat so stewig gevestig is deur Calvyn.

In die tydperk van die laat dertiende eeu tot aan die einde van die sestiende eeu het daar ook op die gebied van die regsontwikkeling 'n hervorming plaasgevind. Tydens die Renaissance en na die postGlossatore het sekere humanistiese regsgeleerdes hulle invloed laat geld dwarsoor Europa. Die Romeinse reg is in die Nederlande geresipieer, maar daar het 'n samesmelting plaasgevind tussen die Romeinse reg en die inheemse gewoontereg. Die samesmelting het gelei tot 'n regsisteem bekend as die Romeins-Hollandse reg. Universiteite is in hierdie tydperk gestig - veral twee was belangrik Leuven (1425) en Leiden (1575) - waar leermeesters van besondere geleerdheid en bekwaamheid studente onderrig het. (Dié leermeesters was juriste wat belangrike werke nagelaat het). Om maar ' $n$ paar groot name te noem wat gedurende die-sewentiende en agtiende eeue geleef en gewerk het, kan daar verwys word na Van der Keessel, Van Leeuwen, Voet, Van der Linden en De Groot.

Die volksplanters aan die Kaap het die Romeins-Hollandse regstelsel saam met hulle na die Kaap gebring. Ondanks invloede van 
die Engelse reg het dit die basiese regstelsel, eers van die drie Republieke sowel as Natal, later van die Unie van Suid-Afrika en nou van die RSA geword.

Wat die Reg betref, is die Corpus Iuris van Justinianus natuurlik in Latyn geskryf. Ook die meeste werke van die regsgeleerdes wat ek genoem het, is in Latyn, die taal van die geleerdes van destyds, geskryf. Sommige daarvan is vertaal in Engels en Nederlands en daar is ' $n$ klein aantal werke wat onlangs ook in Afrikaans vertaal is uitstekende vertalings. Die juris van vandag bevind homself egter in hierdie dilemma dat Latyn in hierdie land besig is om te sterf. Op weinige skole word dit nog as leervak aangebied. Die vereiste van Latyn in die curricula vir die regstudent is al so afgetakel dat dit 'n klug geword het. As 'n regspraktisyn nie Latyn redelik magtig is nie, moet hy liewer nie poog om eers Latynse uitdrukkings in stukke te gebruik nie. Hoe dikwels tref 'n mens nie in stukke aan dat die eiser rente eis "a temporae morae" in plaas van "a tempore morae" nie. Selfs in uitsprake van regters, met alle eerbied teenoor my kollegas, het ek sulke snaaksighede al teengekom soos "naturalium" in plaas van "naturale" as die enkelvoud van "naturalia", of die woord "indi$c a e^{\prime}$ in plaas van "indicia" vir aanduidings. Die argument word gebruik dat dit vir die hedendaagse regspraktisyn nie meer nodig is om Latyn te ken nie, daar word gesê dat as 'n deeglike vermoë om Latyn te kan hanteer nog 'n vereiste moet wees, sal die universiteite nie die aantal regstudente kan lewer wat nodig is om die regspleging aan die gang te hou nie. Dit is ongelukkig waar en ek moét toegee dat 'n goeie kennis van Latyn nie onontbeerlik is vir die alledaagse regspraktyk nie. Maar vir die student wat gevorderde werk doen op die gebeid van die gemene reg, wat die ou bronne wil raadpleeg, is 'n goeie kennis van Latyn 'n absolute vereiste. En as 'n mens die ou bronne raadpleeg, staan jy dikwels nog verbaas oor die rigtinggewende beginsels wat jy daar raakloop. Die probleem is egter nie alleen ' $n$ taalprobleem nie. Dit is ook 'n beskikbaarheidsprobleem. Uitgawes van ou bronne lê verspreid in die biblioteke van universiteite en geregshowe dwarsdeur die land. Ander waarvan ons bewus is, is alleen beskikbaar in biblioteke van veral Holland. U weet wat die gesindheid van die Hollanders vandag teenoor ons is en veral die universiteitsowerhede.

Om die toestand enigsins te verhelp is die Regskommissie tans besig met 'n verskerpte poging om iets aan die saak te probeer doen. Dit is een van die statutêre funksies van die Regskommissie om die 
gemene reg geredeliker beskikbaar te stel. Dit doen die Regskommissie nou. Natuurlik moet daar selektief te werk gegaan word, want sommige geskrifte is, afgesien van die historiese belang wat dit mag hê, glad nie meer belangrik vir die ontwikkeling van ons reg hier te lande nie. Geskikte vertalers word al skaarser. So 'n vertaler 'moet sowel in Latyn as in die Regte onderlê wees om 'n behoorlike vertaling te kan doen. As daar nie gou gemaak word om die belangrikste werke vertaal te kry nie, sal die ou bronne vir die juris in SA, helaas, baie gou letterlik geslote boeke word.

Ook wat die teologie betref neem ek aan dat daar talle ou bronne is wat nog nie vertaal is nie. Ek is nie op hoogte van sake wat betref die onvertaalde werke van die ou kerkvaders gedurende die eerste aantal eeue na die geboorte van Christus nie, ook nie van die werke van die hervormers wat ook grotendeels in Latyn geskryf het nie.

Die Bybel is al soveel keer in Afrikaans vertaal en steeds word daarop verbeter. Die hersiening is nodig, nie alleen omdat die Afrikaanse taal verander nie, maar ook omdat die vertaling self altyd verbeter kan word. As daar nie vertalers is wat ' $n$ goeie kennis het van Hebreeus en Aramees nie, sal hersiening van die vertaling van die oorgelewerde Ou Testament nie moontlik wees nie. As daar nie vertalers is wat 'n goeie kennis van oud-Grieks het nie, sal 'n hersiening van die vertaling van die Nuwe Testament ook ly. $U$ as teoloë vertrou seker dat daar steeds manne sal oorbly wat die vertaling van die Bybel sal kan hersien sowel as die ou bronne kan vertaal, net soos ons as juriste vertrou dat daar steeds geskikte vertalers gevind sal kan word om die regsbronne vir juriste te ontsluit. Ek is seker daarvan dat $u$ wat leermeesters in die teologie is vandag net so oortuig is dat vir 'n behoorlike studie van die Christelike teologie die waardevolle kenbronne ontsluit moet word soos wat die leermeesters in die Regte is dat die kenbronne van die Romeins-Hollandse reg vir die juris van vandag toeganklik gemaak moet word. Beide die bronne oor die Christelike teologie sowel as die bronne van Romeins-Hollandse gemene reg is kosbare erfstukke wat nie alleen as historiese stukke bewaar moet word nie, maar wat steeds gebruik moet word ter uitbouing van ons Christelike en ons regstradisies.

Die Christelike kerk en die regstelsel van hierdie land het 'n lang historiese pad saamgeloop. As ons die Christelike teologie en die regte op 'n suiwere en hoë peil wil handhaaf sal ons steeds moet teruggaan na die bronne om daaruit te put petere fontes. As my 
praatjie van vanmiddag aan $u$, veral $u$ wat verder in die regte en die teologie gaan studeer, enigsins die noodsaaklikheid hiervan tuisgebring het, sal ek dankbaar wees.

Ek wil ten slotte hierdie geleentheid te baat neem om almal van $\mathbf{u}$ wat vanmiddag grade gaan ontvang, asook diegene wat naby $u$ staan en saam met $u$ deel in $u$ prestasie, van harte geluk te wens. Mag $u$ veel sukses en geluk beleef in $u$ onderskeie loopbane hierna. 